\title{
Traditional Balinese Architecture: From Cosmic to Modern
}

\author{
Ronald Hasudungan Irianto Sitinjak ${ }^{*}$, Laksmi Kusuma Wardani, and \\ Poppy Firtatwentyna Nilasari \\ Interior Design Department, Faculty of Art and Design, Petra Christian University, \\ Siwalankerto 121-131, Surabaya 60236, Indonesia
}

\begin{abstract}
Balinese architecture often considers aspects of climate and natural conditions as well as environmental social life. This is to obtain a balance in the cosmos, between human life (bhuana alit / microcosm) and its natural environment (bhuana agung /macrocosm). However, Bali's progress in tourism has changed the way of life of the people, which is in line with Parsons Theory of Structural Functionalism, that if there is a change in the function of one part of an institution or structure in a social system, it will affect other parts, eventually affecting the condition of the social system as a whole. The shift in perspectives has caused structural and functional changes in Balinese architecture. The building design or architecture that emerges today is no longer oriented towards cosmic factors but is oriented towards modern factors, developing in the interests of tourism, commercialization, and lifestyle. The change has had an impact on spatial planning, building orientation, architectural appearance, interior furnishings and local regulations in architecture. In order to prevent Balinese architecture from losing its authenticity in its original form, which is full of spiritual meaning and local Balinese traditions, it is necessary to have a guideline on the specifications of Balinese architectural design that combines elements of aesthetics, comfort, technology, and spirituality. Through this guideline, Balinese architecture can exist in modern times without losing its traditional values.
\end{abstract}

Keywords: Functional, macrocosm, microcosm, traditional value, tri hita kirana.

\section{Introduction}

Traditional Balinese architecture was a result of a long process of Balinese experience in understanding the natural environment as well as the social environment they daily live in. The spiritual values of Balinese Hinduism were profoundly influenced by community systems such as community structure, culture, religion, buildings, and decoration. Natural conditions such as geographical location and climate formed an agrarian society that carved its own identity in the field of architecture.

\footnotetext{
*Corresponding author: ronald_his@petra.ac.id
} 
Social structures dominated by homogeneous agrarian culture gave rise to uniformity in the need for buildings. Balinese people have traditionally been accustomed to working together in all respects, including in the construction of their buildings, such that the results of the architecture are homogeneous.

However, differences still existed because, in everyday reality, community groups formed based on social strata or traditional positions that require differences in spatial planning and use of architectural elements, so that the social status of the owner of a building could be easily recognized visually. For example, the house of a high caste known as puri or jero could be recognized immediately because of its large size and trinket ornaments compared to other houses.
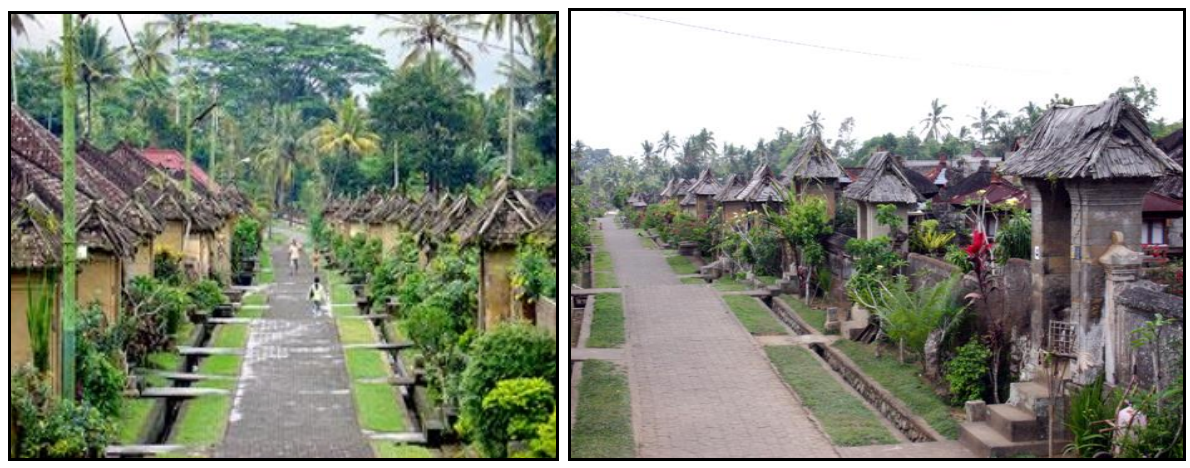

Fig. 1. Homogeneous architecture in the traditional village of Penglipuran, Bali. (Personal documentation, 2006).

Traditionally, the Balinese carried out their life activities as a complete devotion to God, known as the ngayah concept. All things were done voluntarily, sincerely and devotedly so that everything produced was a work that has meaning and charisma known as taksu. In this solid system, every field had experts. In making a building, an expert known as undagi who served as a traditional "architect" based on the ancient Asta Kosala Kosali manuscript, which contains the rules of traditional Balinese architecture [1].

Cosmically, the balance between human life (bhuana alit / microcosm) and its natural environment (bhuana agung/macrocosm) must be maintained [2-4]. Therefore, traditional Balinese architecture always considered aspects of climate, natural conditions, and social life in the arrangement of yards, spatial patterns, construction structures, and selection of building materials by utilizing available materials in Bali in accordance with the conditions of the existing infrastructure.

In modern times, Balinese architecture is shifting. Functional considerations become a new concept to meet the interests of tourism, commercialization, and lifestyle. People's perspectives began to change. This is in line with Parsons' structural functionalism theory, in which changes in one part of a social structure will affect other parts of the structure, which will ultimately affect the overall condition of the social structural system.

\section{Structural functionalism theory}

According to Talcott Parsons, culture is seen as a system, meaning a unity of elements that has a functional relationship with one another, so that if one element changes, it will also result in a change in the overall system [5]. A society can be seen as a social system or institution, which consists of various parts or elements, related and dependent on one another in an equilibrium, categorized as a system of stable social interaction. Every 
institution or structure in a social system is functional towards the others. Therefore, if there is a change in one part, it will affect the other parts which ultimately will affect the condition of the social system as a whole. In general, these institutions model human activities based on norms shared values, and are considered valid, binding on the participation of their members [6]. Hence, if there is a change in a functional social system, then the elements associated with the social system will change as well. If the structure changes, the infrastructure will also change.

To the traditional Balinese people, whose lives were still oriented towards the cosmic realm, their life infrastructure was also oriented towards the cosmic realm. The design of a building or its traditional architecture - as an infrastructure - always considered natural and climatic factors, both macrocosm and microcosm, such as the orientation pattern of developing traditional architecture that were built based on natural and spiritual elements, for example: the concept of kaja-kelod, kangin-kauh, the concept of natah as the center of orientation in the middle, the concept of the tri mandala, the concept of the tri angga, the arrangement of residential space patterns, and so on [7].

In subsequent developments, with the influence of modern culture, the orientation of traditional community life tends to shift to modern orientation. The Balinese social system is slowly undergoing change. This change has had an influence on other cultural elements that have a functional relationship with the Balinese people. The building design or architecture that appears to be following the change is no longer oriented towards cosmic factors but are oriented towards modern factors.

\section{The cosmology of traditional Balinese architecture}

Traditional Balinese architecture that attempted to maintain a balance between human life and its natural environment, always considered aspects of climate and natural conditions as well as social life in the arrangement of yards, spatial patterns, construction structures, and selection of building materials by utilizing materials available in Bali in accordance with existing infrastructural conditions.

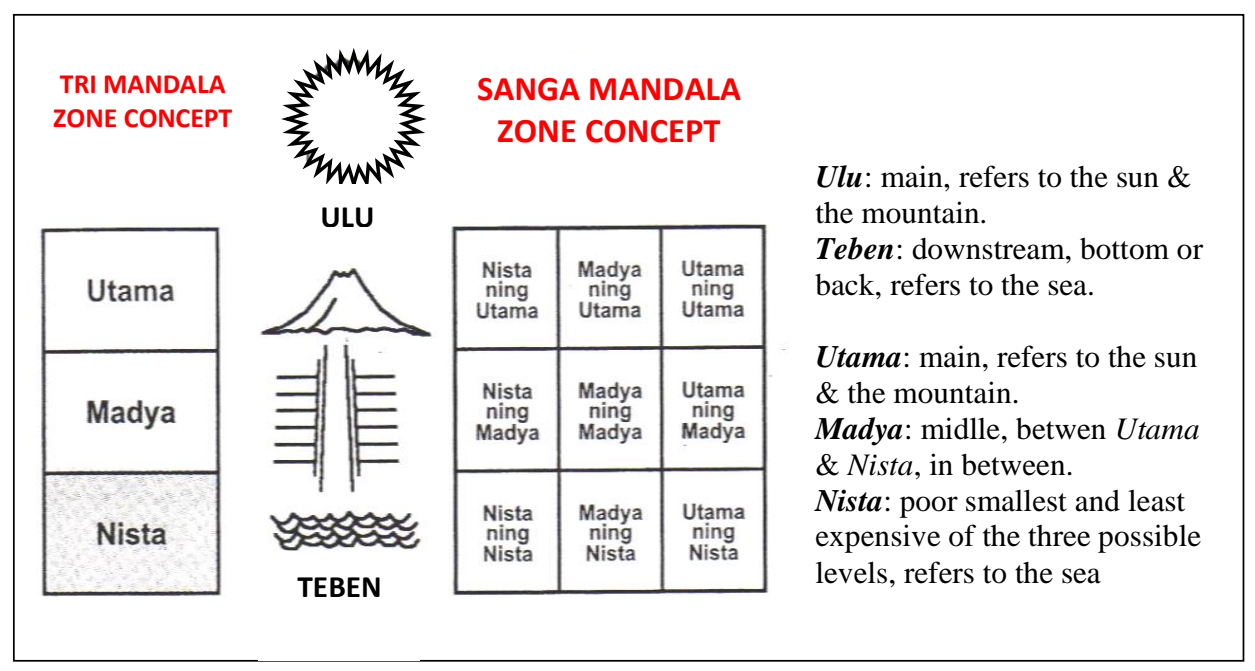

Fig. 2. The Tri Mandala and Sanga Mandala zone concepts [3, 4, 8].

The pattern of direction orientation in the development of traditionaldarchitecture also refered to natural and spiritual elements. Horizontally, Mount Agung was perceived as the 
main (kaja) orientation; the sea as the orientation of the kelod (nista); the line between sunrise and sunset was known as kangin (main) and kauh (nista). The kaja-kangin position had the highest spatial hierarchy. Vertically, the top and bottom were known as ulu and teben [7].

In the physical embodiment (three dimensions) each architectural building was vertically required to follow the concept of triangles so that there were always parts of the head (roof), body (walls enclosing a space) and legs (the bottom, building foundation) that represented the utama, madya, and nista [7].

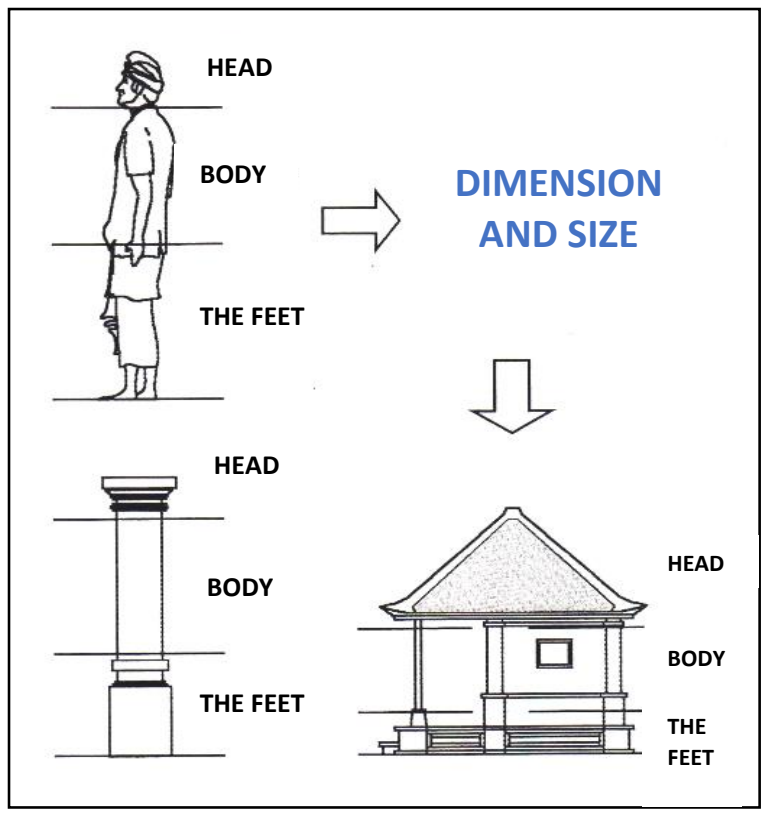

Fig. 3. The Tri Angga concept in building [2].

Besides referring to the cosmic principle, time was an important factor influencing traditional Balinese architecture. Time was seen as something that was repeated, slow, in the form of an eternal circle, as reflected in daily life when planting or harvesting rice, the full-dead months, and the philosophy of birth-life-death and its repetition. There was no beginning or end; everything repeated itself. Time was not something that was linear, like in the Western world.

Traditional Balinese culture grew from several previous cultures. The Bali Mula culture was simple in character. Its architectural elements were made of objects around the settlement that cannot resist the weather conditions, and hence so it did not have a lot of heritage. The Bali Aga culture that formed natural objects architecturally was arranged in harmony to maintain a balance between humans and their natural environment. There were many relics in its interior space. Arya Balinese culture brought Majapahit cultural influence to Bali by presenting new forms of architecture such as the bentar temple (gate) and Hinduthemed ornamental elements whose remains are still often found today [9].

For their residence, traditional Balinese people made compound building facilities whose hierarchical arrangement followed the orientation of the direction as described above. The arrangement was truly communicative, where indoor-outdoor activities were proportionately met, by presenting a communal outdoor space called Natah, as the center of orientation located in the middle of the compound $[2,10]$. The concept of natah as the 
center of orientation in the middle was lifted from the Tapak Dara and the Swastika pattern (in Balinese Hindu culture), whose central axis is emptiness/Akasa.

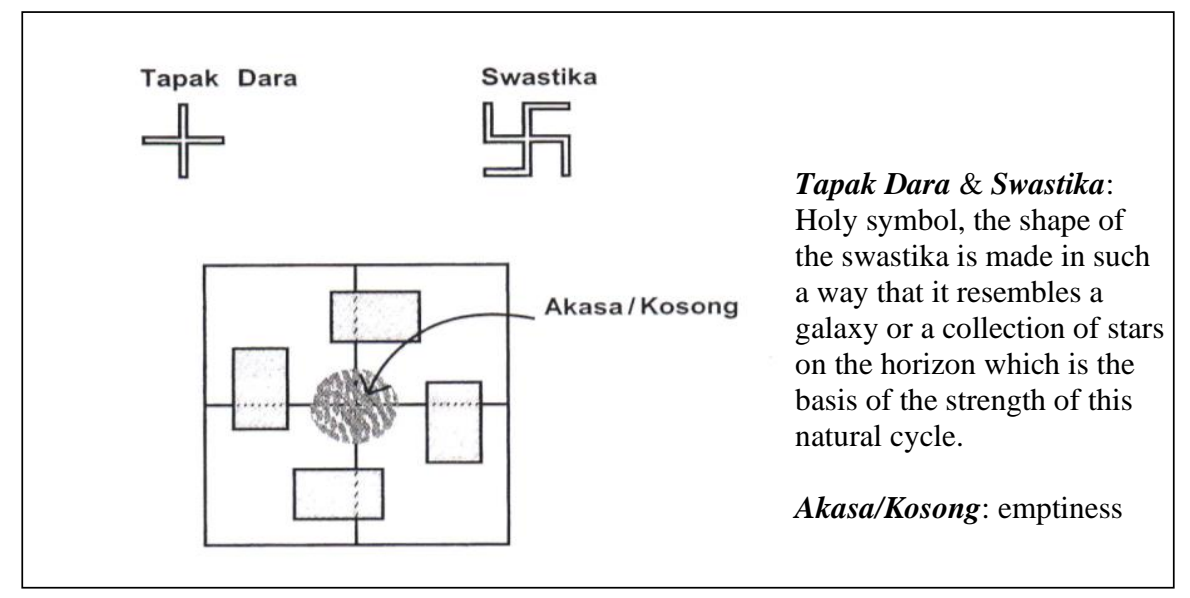

Fig 4. Tapak Dara and Swastika patterns were articulating emptiness/Akasa on its central axis [2].

The space for performing joint activities was accomodated by an open pavilion with a structural frame, made of wood and exposed roof truss combined with bamboo. The material was made of natural materials such as stone, unburned bricks, wood, bamboo, and reeds. The Parahyangan or place of worship of God on the scale of the household, which was considered to have the highest hierarchy, was placed in the kaja-kangin position. Meanwhile, the kitchen and gates, that were considered to have the lowest hierarchy were placed in the kelod-kauh position or in the teben area.

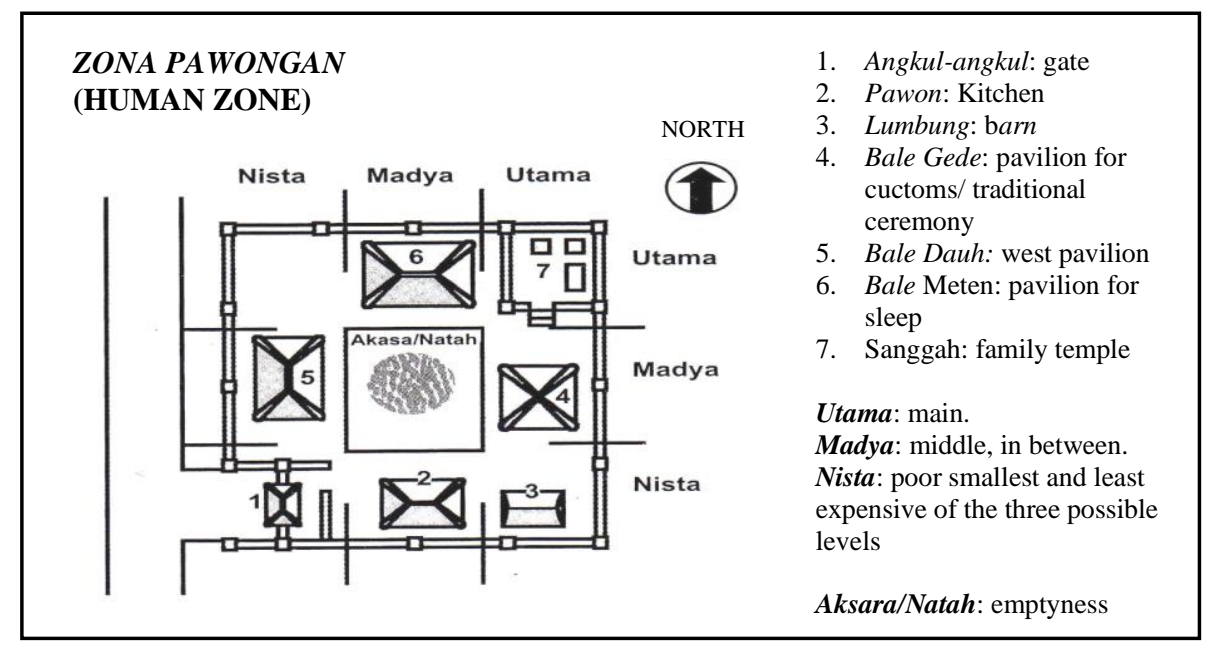

Fig. 5. Traditional Balinese house plan [2].

To measure the distance between each building within the scope of a traditional Balinese house plan, there were standard rules, as set out in the following figure: 


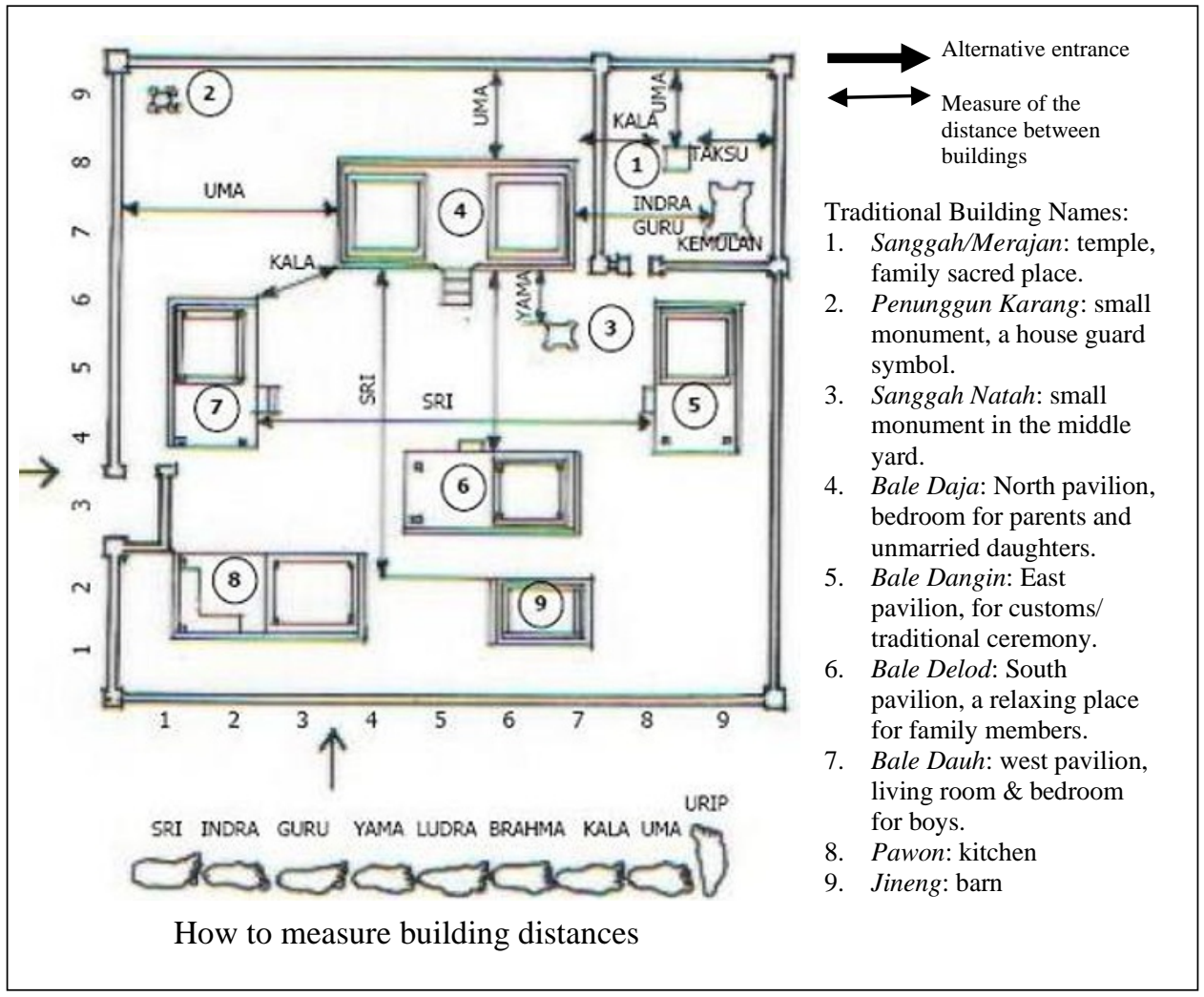

Fig. 6. How to measure the distance between buildings in the scope of traditional Balinese dwellings $[3,8,11]$.

\section{Changes in traditional Balinese architecture}

The revolutionary change and development of traditional architecture can be said to have started since the entry of foreign culture outside Bali, which was brought in by world explorers who became attached to the island and stayed behind to be part of Balinese society and culture. In general, they were people who lived off from art, who was inspired to work in Bali. The period of Dutch colonialism was also an important point in the development of architecture in Bali. It was the colonialists who first introduced modern buildings made of burnt bricks with a supporting wall structural system. At first, this kind of building was still limited to colonial buildings and offices. The traditional Balinese society in the early 20th century referred to all modern brick-walled buildings as "office buildings" [12].

Since tourism in Bali developed rapidly in the 1980s, the agricultural sector was no longer the main livelihood of the Balinese people. Various business services in the field of tourism, such as the procurement of hotels and other tourism facilities and commodity trading related to tourism needs, were increasingly in demand. This was followed by the rapid construction of international-standard hotels in tourist destination areas such as Ubud, Sanur, Kuta, and Nusa Dua. The hotels were designed to follow the traditional Balinese architectural style to meet market demands for local identity, both in the interior and exterior. The goal was that tourists could gain the maximum visual atmosphere to confirm their presence in Bali. All equipment that had become a standard of Western comfort must also be present for the convenience of tourists. Eventually, there was a compromise process 
for architects to be able to optimally combine the advantages of both Eastern (Bali) and Western architecture.

Cultural-shock occured between Balinese culture that was traditionally preserved and foreign (Western) cultures that entered Bali. The hotel was considered a standard of luxury and establishment. Architectural design with the form of assimilation (adjustment) between the modern and traditionally used in hotels began to be widely imitated for public buildings and residences. This imitation certainly caused problems because basically every architectural design was the final product of a process of in-depth analysis of the environment, site, functions, activities in it, and the character of the building user. Discrepancies in use will definitely arise if the same design was applied to the character of buildings from different cultures. An architectural structuring system that was in accordance with traditional rules was no longer possible in the midst of the urban development that does not anticipate the maximum volume of transportation facilities, limited land area, very high prices, and several other factors [2].

The price paid for change was not a cheap one. In the context of architecture, there has been a cultural adaptation to produce something that could no longer be claimed as belonging to the traditional Balinese community as a whole. There was a transition phase between the traditional cosmic to the modern. People who were still bound by patterns, styles, and old styles, began to recognize new forms, and open up to new design choices that show that today's society has the honesty to recognize their identity as an agent of the transitional era.

Only because of reasons to find solutions to problems of form and space, they mimiced the form that was not in accordance with the character and personality of Bali people, and hence, the design adopted does not have a clear identity. The application of form becomes inappropriate; in this case, there is "confusion in aesthetics." The selection of eclectic design is sometimes only a reflection of naivete, including when traditional designs are then used as a means to show a certain social status. Modern education patterns that provide equal opportunities for all levels of society to achieve their respective positions are very influential on the socio-economic life of the Balinese people. Along with that, the standard rules of architectural identities could be broken down by anyone with economic capacity. In heterogeneous urban societies, architectural identity is no longer based on the traditional rules of Asta Kosala Kosali as in the traditional society but solely based on economic capabilities that often produce aesthetic tastes. This phenomenon is a sign of the emergence of new feudalism in Balinese society [2].

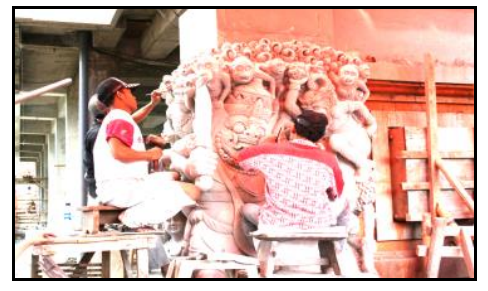

Fig. 7. Two undagi are working on the ornamentation of a building (Personal documentation, 2005).

In line with the times and modernization, the development of traditional architecture also began to be influenced by aspects of modernization such as building functions which emphasize on the aspects of effectiveness, efficiency and comfort, which are the demands of the modern society, adding to the color of the traditional Balinese architecture that is currently developing. This development gives rise to contradictory conditions in the ability of an undagi (traditional Balinese architects/designers) who have been accustomed to the 
dimensions of traditional rules yet having to accommodate the development of modern architecture with its modern dimensions.

The modernity that we find today can be translated as a symptom of superficial cultural adoption without any consideration to in depth understanding of the meanring behind the adoption. Reflecting on these conditions, it is necessary to make an effort to help the community understand their true identity, avoid their denial of identity, by departing from distinct roots to achieve maximum end result aesthetically. This also becomes a part of the architect/designer's responsibility in producing a work that is full of meaning.

The change in time that has caused cultural shifts in the Balinese society has ultimately affected the traditional architecture/buildings of Bali. Therefore, it can be observed the impacts by following further discussions.

\subsection{Spatial planning}

At present, the spatial layout applied in the architectural planning of Bali is based on urban spatial planning habits. This is inseparable from the shifting patterns of life to become more efficient, supported by a variety of new facilities or infrastructure that is now a part of the daily life of the Balinese. There is no longer any macro space that is designed to follow the old pattern that tended to be religious: the Great Pangkalan as the main core of a physical structure complete with Pura facilities as spiritual facilities, Puri as a center of government control, markets as economic facilities, and the square as an open space for mass/ communal community activities. This simple pattern is no longer possible to accommodate the socio-economic complexity of the present society.

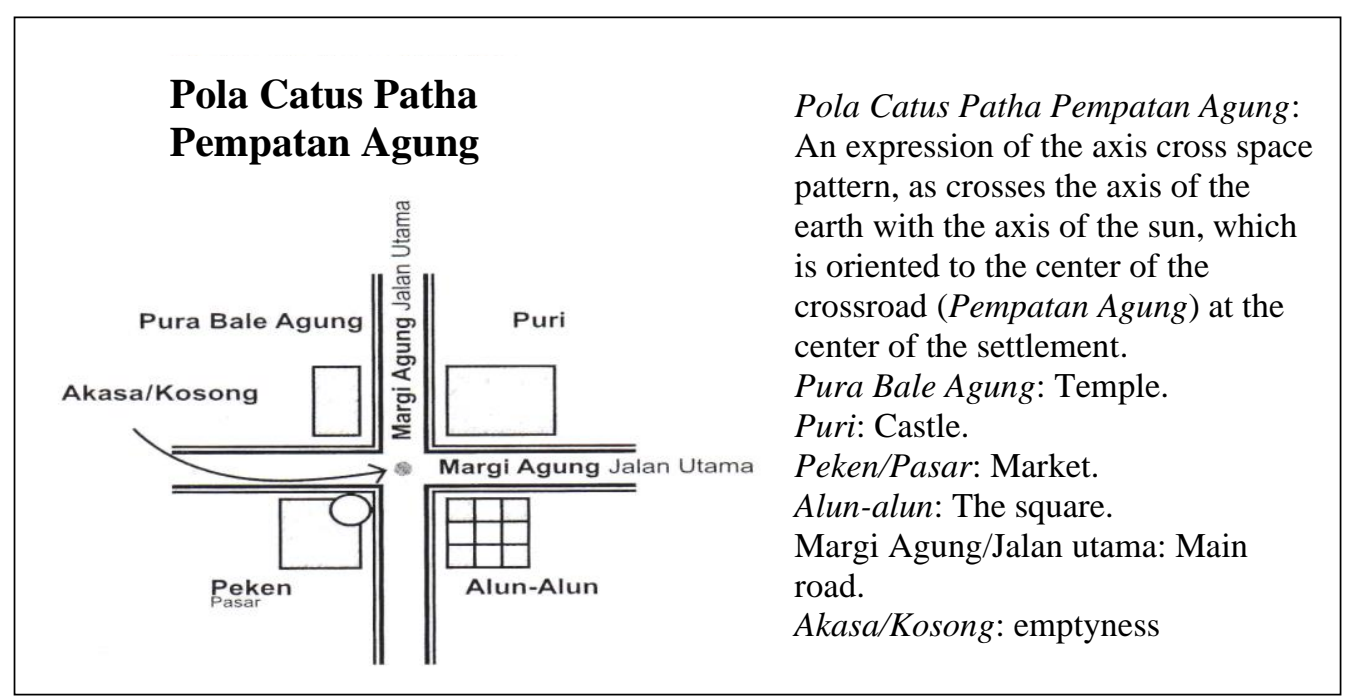

Fig. 8. Pempatan Agung spatial planning as the main core [2].

However, the spatial planning still follows traditional patterns in the micro scale, especially by those who still carry out Balinese culture or those who have enough land to implement traditional Balinese spatial patterns that tend to demand large areas of land. It is also generally not followed holistically, but only to the extent of placing the most important units in a compound at their correct position according to traditional rules.

To overcome the limitations of land, there was a tendency to construct buildings vertically. This was adopted by some Balinese who took the initiative to make their own interpretations by placing units that were considered to have a higher hierarchy on a higher 
floor. This case was mostly found in urban areas. Interestingly, because the pattern of development had been directed vertically, the horizontal hierarchy of space was often overlooked. This phenomenon, in addition to giving rise to pros and cons, had also created various versions of architectural modifications due to the absence of clear guidelines or rules as in traditional architecture. This needs to be examined in order to create the same perception of the design provisions in the latest generation of Balinese architecture, which can be continued as a response to mediate traditional Balinese buildings with Modernism and respect the noble rules of its root architecture.

\subsection{Orientation}

In line with the changing patterns that are currently prevailing in the society, in relation to development and architectural issues, there has also been a change in views about the ideal conditions of land for development. In the old pattern, the land that was considered of high value was located on the edge of the highway. The larger the road, the higher the price of the land. However, after tourism has developed rapidly in Bali, the land that has a higher selling power for the tourism industry is the land that has more beautiful views such as those on the beach or on the edge of a valley (cliff).

This shift of this view created a change in terms of orientation in contemporary architectural planning in Bali. Traditional architecture that was indoor-oriented, known as the natah pattern (see Figure 5), has turned into a modern architecture with nuances of tourism that is outward-oriented to the outdoor view. The beautiful and expensive landscape became so important such that all kinds of building planning in Bali would be focused or directed at it, ignoring the rules of orientation that apply to traditional architecture. In general, it can be said that there has been a change in planning orientation: from the old pattern, which was indoor-oriented to the new pattern which is outdoororiented.

\subsection{Architectural appearance}

Traditional Balinese architecture tended to appear humble (low profile) and is generally surrounded by a parapet wall that functions as security as well as to maintain the privacy of each building. Traditional Balinese architecture did not recognize the existence of multistorey functional buildings. There was rarely a striking difference in building height from one another. The humble impression also arised from the use of natural building materials so that they appear in harmony with the surroundings, even though it may seem monotonous.
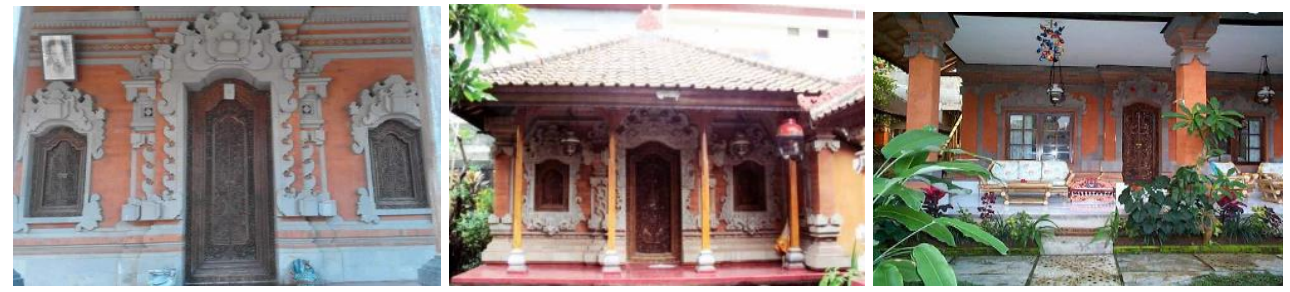

Fig. 9. The different faces of balinese architecture yet retaining some similarity in the use of the natural material such as bata-bali as well as ornaments.

(Source: https://www.mentaribaliholiday.com/2016/01/inilah-desain-bentuk-rumah-stil-bali.html; https://www.baabun.com/rumah-adat/rumah-adat-bali-2/; http://gema-

budaya.blogspot.com/2012/01/rumah-adat-bali.html). 
The process of Modernism influenced architectural development in Bali, offering a variety of choices and new technologies for the provision of building materials that created a vast opportunity for the development of new designs. Because these new materials and technologies tend to be artificial and appear in a variety of colors and textures, especially for finishing, the architecture in Bali appeared to be shifted from its roots. This phenomenon rose not only because of economic-practical factors but also because of the individualistic nature of heterogeneous modern societies that tend to seek ways to display their identities and not willing to be similar to other designs. Individual pride also caused them to use their building architecture to prove their economic strengths compared to others. What is currently interesting in Bali is the phenomenon of neo-feudalism in the society that raises a strong tendency to make these buildings as an exhibition of economic establishment, as well as to show the identity of the background of kinship (clan/caste), after presenting the building with a look that is full of modern finishing materials. In some cases, this renewal in appearance made the buildings look even more suitable, yet many also appear odd.

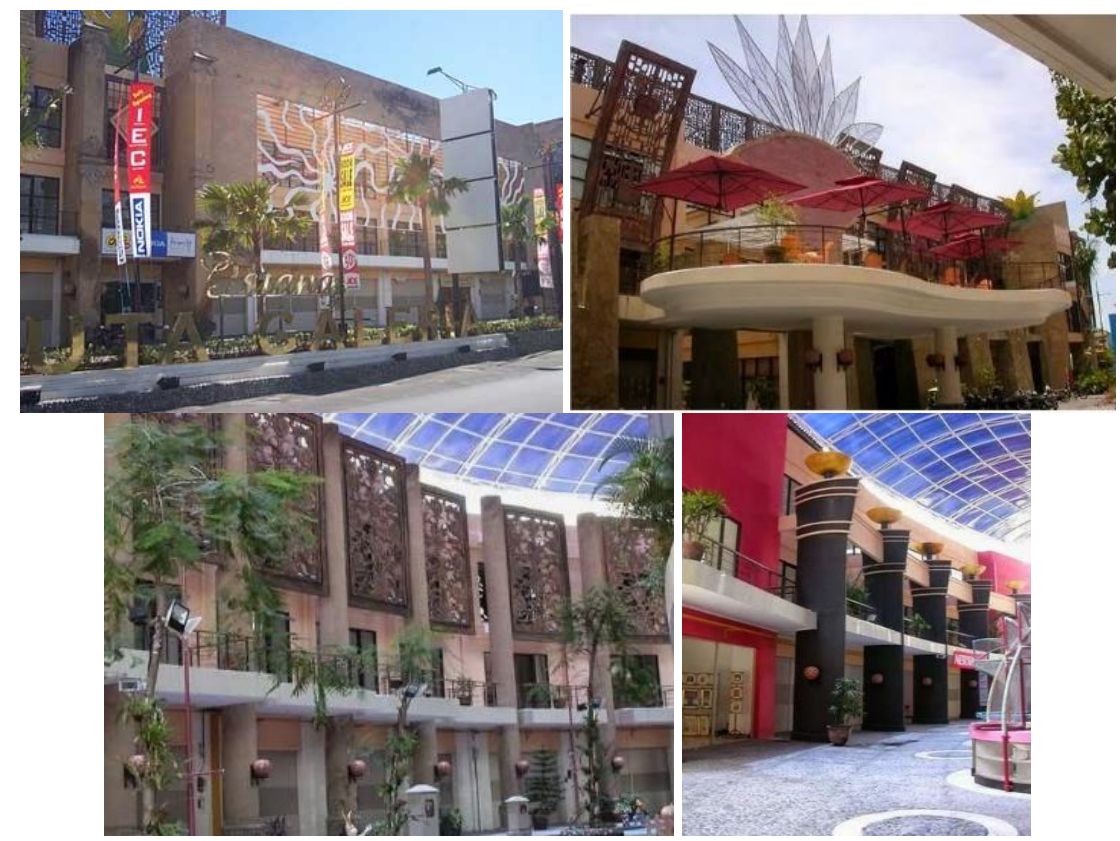

Fig. 10. Istana Kuta Galeria Mall Bali, Architecture with Modern Finishing that Brings New Color to the Face of Balinese Architecture.

(http://www.balitoursclub.com/berita_138_Istana_Kuta_Galeria.html; http://roxuai.blogspot.com/2014/06/istana-kuta-galeria-bali.html).

However, the determination of indigenous people still exist, who uphold their cultural roots in traditional architecture according to the original Balinese design concept such as the incorporation of a gate (candi bentar, kori), open pavilion (bale), and the granary (jineng/kelumpu). 

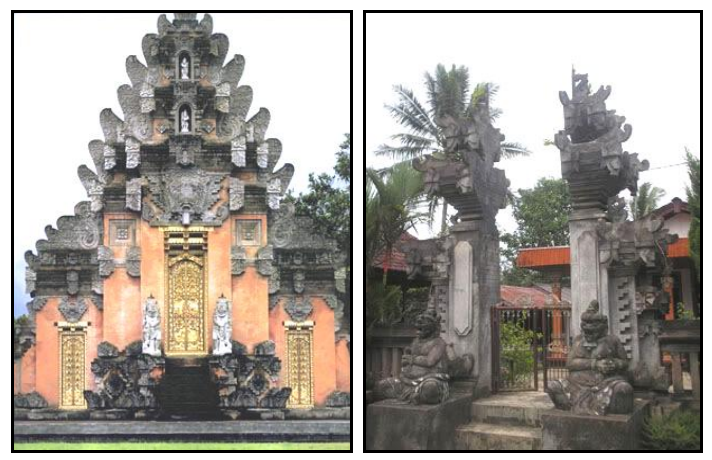

Fig. 11. Entrance gate (Candi Bentar \& Kori) in Balinese traditional building (Personal Documentation, 2005).

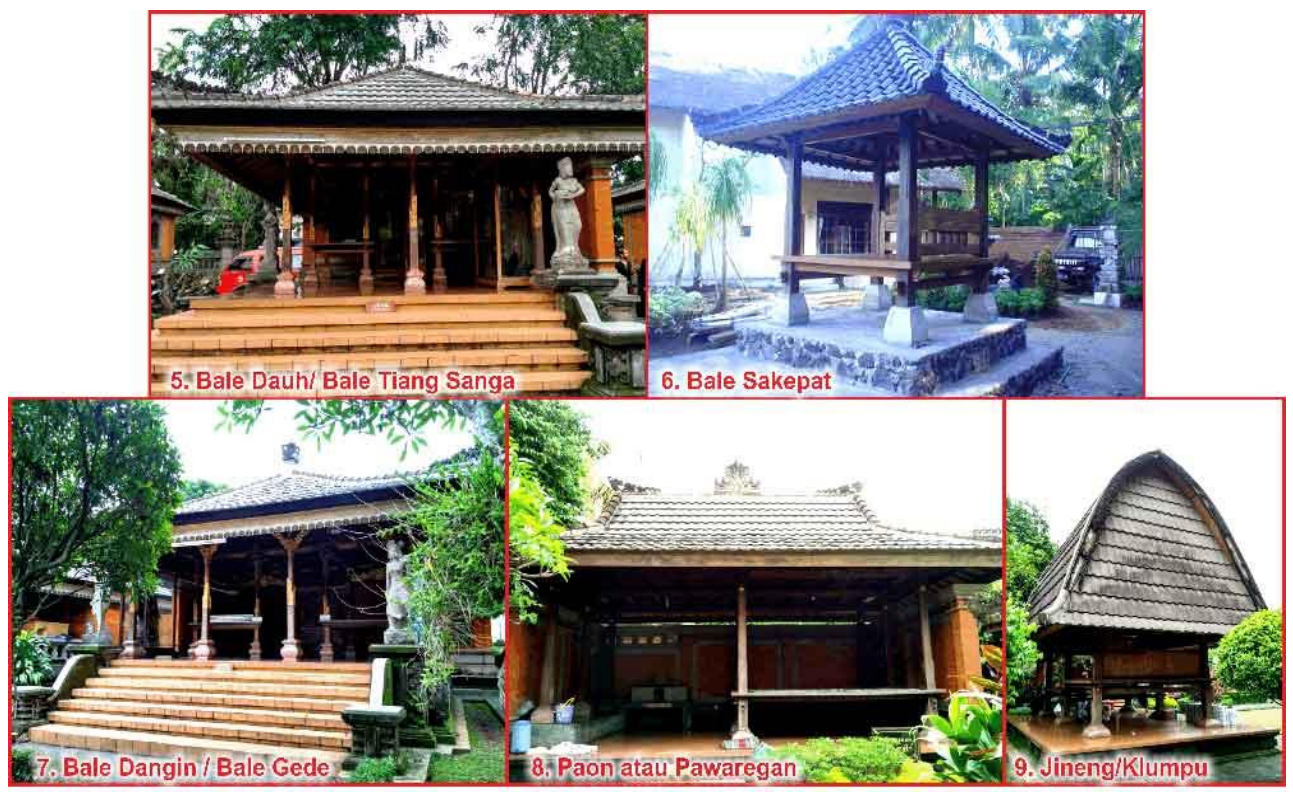

Fig. 12. Open pavilion is known as Bale and Granary, known as Jineng/Kelumpu (https://www.senibudayaku.com/2018/01/rumah-adat-bali.html).

\subsection{Interior furnishing}

In addition to new building materials that have altered the appearance of architecture in Bali, culture-shock has also taken place in the use of elements that complement the modern interiors, especially those concerning people's living habits or daily activities. The development of modern interior furnishings in line with the increasing purchasing power of the Balinese people has encouraged them to build with the latest interior furnishings available in the market.

Many interesting examples have occurred in essential home facilities, such as bathrooms and kitchens. While the trend and purchasing power allows people to adopt modern (dry) bathrooms, the habit of using wet bathrooms still cannot be escaped. As a result, there are often deviations from the use of these facilities. Many still treat dry 
bathrooms as wet bathrooms, and bathtubs, which are the icon of dry bathrooms, have even been used to soak laundry.

This is also the case in kitchen facilities. People tend to come up with modern kitchens (clean kitchens) that are more suitable for Western-style food processing. In reality, they cannot leave the habit of processing and enjoying local foods that their taste has been accustomed to. Due to this phenomenon, it has become a norm in a house to have two kinds of kitchens, which are now referred to as a clean kitchen (Western) and a dirty kitchen (Bali).

\subsection{Regional regulation on architecture}

As an effort to preserve traditional Balinese architecture, the Local Government of Bali, through its regional regulations (Perda No. 2, 3, 4, Th. 1974), requires every building in Bali to appear reflecting traditional Balinese architecture. This is a positive idea that truly needs to be supported as long as this idea is followed up by making detailed provisions in the form of design manuals that make it easy for the public to carry out the government's wishes.

However, due to the lack of detailed explanation and understanding, the regulation was then interpreted as being limited to the obligation to provide Balinese "cosmetic" or surface makeup in every architectural embodiment. This situation has made an impact on the identity of the function or designation of each building. The newcomers who are not yet familiar with the existence of facilities in Bali, finally find it difficult to distinguish private buildings, offices, or other public facilities because they all wear similar attributes. This uniform appearance of architecture that is generally accepted in Bali has resulted in a blurring of regional identity in Balinese architecture, which for centuries has been wellpreserved and has lived coloring the local Balinese architecture.

\section{Conclusion}

The entry of modern culture into Bali has made the cosmic-oriented world of traditional Balinese architecture change its direction to the orientations carried by modern culture. However, despite the various problems mentioned above that colored the journey of architectural development in Bali, it must also be recognized that from the winding journey, Bali has unwittingly developed its own attraction in combining traditional architecture with the needs of modern living facilities. Many hotels in Bali are considered to have high uniqueness, because of the success in presenting authentic Balinese architecture, which is able to tell about a specific product that only exists in Bali. The Balinese people have made themselves as parts or perpetrators of this process of change, which still adheres to traditional religious rules that are universal. In connection with the development of Balinese architecture at this time, the Balinese people still show a tendency to obey traditional rules (Asta Kosala Kosali) as a foundation for traditional buildings such as parahyangan, pawongan (housing) and buildings for death ceremonies of death (pepaga, bade, etc.). As for non-traditional buildings, traditional rules are not absolutely obeyed and even tend to be ruled out, replaced by modern rules.

In its latest condition, the Balinese style in architecture, which has become known as Bali style, has become a world consumption because it is considered a trendy style. Many foreigners would obtain a deep impression after their visit to Bali, and desire brings back something, whether as an interior element or massive structure and for their personal or commercial interests, which could architecturally be considered "Balinese" in their country. Market demand for this kind of commodity can already be well-fulfilled by its suppliers in Bali because technological assistance has been used to facilitate knock down systems, and 
the available cargo facilities make it easy to make shipments. Hence Balinese architecture has created both a business opportunity that must be welcomed and an effective means of promotion for Bali. However, this needs to be anticipated wisely because Balinese architectural styles that have been constructed based on tropical climate conditions are not always appropriate for use in every part of the world. If the "finished building" traders (exporters) only think of a short-term business without examining their appropriateness in the ordering country, it is not impossible that Balinese architecture would get a bad image because of its limited durability in an inappropriate climate.

From an architectural and interior design point of view, Balinese people should be proud of their unique "Balinese style," which is not only beautiful to look at but also has a magical element. The development of architecture and interior design has been accelerating lately because it is driven by tourism, which requires the presence of a Balinese identity as a selling power and is driven by the availability of various types of material from Western (Modern) cultural works. Bali is a heaven for architects and interior designers because they can easily realize their creativity, assisted by skilled and thorough craftsmen, and also because of the availability of various types of materials.

In addition to these realities, Bali certainly needs a guideline from the local government regarding design specifications that combine elements of aesthetics, comfort, technology, and spirituality. This guideline is even more urgent because Bali is now in a transition period from the traditional society to modern society, with an increasingly dense population and the ability to buy modern architectural and interior products.

Hence, the task of architects and interior designers as current planners is to have the will to formulate a clear design implementation guideline. This would fulfil the nation's goal in establishing internationally-standard public facilities that are characterized by the "Bali style" (Balinese form and meaning) as a distinct pride and identity in the globalized world.

\section{References}

1. N.K.A. Dwijendra. Arsitektur Bangunan Suci Hindu: Berdasarkan Asta Kosalakosali, [Architecture of Hindu Sacred Buildings: Based on Asta Kosala-kosali], Denpasar: Udayana University Press (2008) [in Bahasa Indonesia]. https://books.google.co.id/books/about/Arsitektur_bangunan_suci_Hindu.html?id=oB NaPgAACAAJ\&redir_esc $=$ y

2. P. Danes. Arsitektur Bali [Bali Architecture], In: Bali - Dalam Dua Dunia [Bali on two world dimension], U. Ramseyer, I.G.R.P. Tisna, R. Surya (Eds), Bali: Matamera Book (2003). https://books.google.co.id/books/about/Bali.html?id=91NxAAAAMAAJ

3. N.P. Aryani, Journal of Architecture and Environment, 12,113-124(2013). http://iptek.its.ac.id/index.php/joae/article/view/561/710

4. I.G.B.W. Kusuma, Humaniora, 15:62-73(2003). https://media.neliti.com/media/publications/11804-ID-building-orientation-ontraditional-balinese-culture.pdf

5. I. W. Dana, Tokoh-tokoh Teori Strukturalis. [Theory of Structuralism], Paper presented at the Cultural Theory Class, Postgraduate Program, Indonesian Art Institute in Yogyakarta (Yogyakarta, 2009). [Online unpublished]. [in Bahasa Indonesia].

6. Y.S. Hadi, Seni dalam Ritual Agama, [Art in Religious Rituals], Yogyakarta: Penerbit Buku Pustaka (2006). [in Bahasa Indonesia]. https://openlibrary.org/books/OL16352815M/Seni_dalam_ritual_agama

7. J.H. Peters, Tri Hita Kirana: The Spirit of Bali. Jakarta: KPG (2013). https://www.amazon.com/Tri-Hita-Karana-Spirit-Bali/dp/9799106370 
8. N.K.A. Dwijendra, Arsitektur Rumah Tradisional Bali, [Architecture of a Traditional Balinese House], Denpasar: Udayana University Press (2008). [in Bahasa Indonesia]. https://books.google.co.id/books/about/Arsitektur_rumah_tradisional_Bali.html?id=qd cOAQAAMAAJ

9. C. Holt, Melacak Jejak Perkembangan Seni di Indonesia [Trace the Traces of Art Development in Indonesia], Bandung: Arti line (2000). [in Bahasa Indonesia]. https://openlibrary.telkomuniversity.ac.id/pustaka/144487/melacak-jejakperkembangan-seni-di-indonesia.html

10. M. Permana, E. Basuki, N. Sari, Arsitektur E-Journal, 3:75-90(2010). [in Bahasa Indonesia].

https://www.academia.edu/7024429/Perubahan_Pola_Ruang_Tradisional_Desa_Adat _Tenganan_Pegringsingan_Karangasem-Bali

11. J.M. Pulasari. Cakepan Asta Kosala-Kosali. Surabaya: Paramita (2007). p. 108. [in Bahasa Indonesia].

https://books.google.co.id/books/about/Cakepan_asta_kosala_kosali_lan_asta_bhum.h tml?id=ijWJRQAACAAJ\&redir_esc $=\mathrm{y}$

12. J. Prijotomo. Pos Kolonialisme: Lingkung Bina di Indonesia - Perbincangan di kekini-an. [Post Colonialism: The Circle of Development in Indonesia - Discussion in the present-day]. Paper presented at a meeting between the Surabaya Institute of Technology Architecture Postgraduate Program, Udayana University and the Indonesian Institute of Architects Bali (Surabaya, 2001). [in Bahasa Indonesia]. https://onesearch.id/Record/IOS4937.ai:oms-7118 